\title{
Antiparasitic, physiological and histological effects of the essential oil of Lippia origanoides (Verbenaceae) in native freshwater fish Colossoma macropomum
}

\author{
Bruna Viana Soares ${ }^{\mathrm{a}}$, Adriele Carolina Franco Cardoso ${ }^{\mathrm{a}}$, Rosilene Ribeiro Campos ${ }^{\mathrm{c}}$, Bianca Barata Gonçalves ${ }^{\mathrm{d}}$, \\ Gracienhe Gomes Santos ${ }^{\mathrm{d}}$, Francisco Célio Maia Chaves ${ }^{\mathrm{e}}$, Edsandra Campos Chagas ${ }^{\mathrm{e}}$, Marcos Tavares-Dias ${ }^{\mathrm{a}, \mathrm{b}, \mathrm{d}, \mathrm{d}}$ \\ a Programa de Pós-Graduação em Biodiversidade Tropical (PPGBIO), Universidade Federal do Amapá (UNIFAP), Macapá, AP, Brazil \\ b Programa de Pós-Graduação em Biodiversidade e Biotecnologia (BIONORTE), Universidade Federal do Amapá (UNIFAP), Macapá, AP, Brazil \\ ${ }^{\mathrm{c}}$ Universidade Federal do Amazonas, Manaus, AM, Brazil \\ ' Embrapa Amapá, Macapá, AP, Brazil \\ e Embrapa Amazônia Ocidental, Manaus, AM, Brazil
}

\section{A R T I C L E I N F O}

\section{Article history:}

Received 21 October 2016

Received in revised form 29 November 2016

Accepted 1 December 2016

Available online 10 December 2016

\section{Keywords:}

Monogenoidea

Parasites

Medicinal plant

Blood

Tambaqui

\begin{abstract}
A B S T R A C T
This study examined the in vitro and in vivo, histopathological, anti-parasitic and hematopathological effects of the essential oil of Lippia origanoides on Colossoma macropomum. Essential oil concentrations of 10, 20, 40, 80, 160 and $320 \mathrm{mg} \cdot \mathrm{L}^{-1}$ were tested in vitro against monogenoideans (Anacanthorus spathulatus, Notozothecium janauachensis and Mymarothecium boegeri) from the gills of C. macropomum. Concentrations of 320 and $160 \mathrm{mg} \cdot \mathrm{L}^{-1}$ were $100 \%$ effective against these parasites within 20 and $60 \mathrm{~min}$ of exposure, respectively. The $80 \mathrm{mg} \cdot \mathrm{L}^{-1}$ concentration was approximately $80 \%$ effective with $3 \mathrm{~h}$ of exposure, reaching $100 \%$ with $6 \mathrm{~h}$ of exposure. The $40 \mathrm{mg} \cdot \mathrm{L}^{-1}$ concentration was also $100 \%$ effective with $6 \mathrm{~h}$ of exposure. The other concentrations were only weakly effective in vitro. Parasite mortality in controls (water or water + alcohol) began after $3 \mathrm{~h}$, with $100 \%$ mortality after $8 \mathrm{~h}$. In vivo tests, in which fry of C. macropomum were placed in baths with $20 \mathrm{mg} \cdot \mathrm{L}^{-1}$ of the essential oil for $60 \mathrm{~min}$, and $40 \mathrm{mg} \cdot \mathrm{L}^{-1}$ for $30 \mathrm{~min}$, did not lead to reductions in parasite abundances. In addition, the essential oil had an anaesthetic effect on fish, increased total protein levels, increased monocyte and neutrophil numbers, and reduced haematocrit. Slight to moderate and severe damage was observed in the gills of C. macropomum fingerling immediately after exposure to the essential oil, and $24 \mathrm{~h}$ after the treatments were applied, with no difference between treatments. Histological changes observed in the gills after exposure to concentrations of 20 and $40 \mathrm{mg} \cdot \mathrm{L}^{-1}$ of L. origanoides essential oil were: hyperplasia and fusion of the lamellar epithelium, capillary dilation, displacement of the lamellar epithelium, and lamellar aneurism and epithelial rupturing with haemorrhaging. Oedema, mucous and chloride cell proliferation, lamellar hypertrophy, congestion and necrosis were less frequently observed. It can be concluded that the essential oil of $L$. origanoides was dose-dependent in vitro effect against monogenoidean parasites of C. macropomum. Unfortunately, the low concentrations tolerated by the fish in the vivo assay $\left(20\right.$ and $\left.40 \mathrm{mg} \cdot \mathrm{L}^{-1}\right)$ was not effective.

Statement of relevance: The manuscript represents original research on use of the essential oil of Lippia origanoides against ectoparasites of Colossoma macropomum, an important finfish of Amazon region. This manuscript includes treatment in vitro against monogenoideans, and in vivo against protozoans and monogenoideans. Besides, histopathological and hematological analysis of the fish exposed to different concentrations of $L$. origanoides, a medical plant from North, Central and South America, were performed.
\end{abstract}

(c) 2016 Elsevier B.V. All rights reserved.

\section{Introduction}

Lippia origanoides Kunth (Verbenaceae), is an aromatic shrub found from Southern North America, through Central America, to the north of

\footnotetext{
* Corresponding author at: Embrapa Amapá, Rodovia Juscelino Kubitschek, km 5, 2600 68903-419 Macapá, AP, Brazil.

E-mail address: marcos.tavares@embrapa.br (M. Tavares-Dias).
}

South America. In the Brazilian Amazon, L. origanoides is an important medicinal plant due to therapeutic and culinary uses. Ethno-botanic studies indicate uses of $L$. origanoides to treat gastrointestinal, urogenital and respiratory problems, and as an anti-malarial (Ribeiro et al., 2014; Soares and Tavares-Dias, 2013; Oliveira et al., 2007; Vásquez et al., 2014). Bioactive products obtained from $L$. origanoides have also antioxidative effects, insecticidal properties against Aedes aegypti, antimicrobial and anti-protozoal effects, antigenotoxic properties, and are insect 
Table 1

Chemical constituents of the essential oil of Lippia origanoides.

\begin{tabular}{llll}
\hline Peak & \% content & Retention index & Identification \\
\hline 1 & 0.5 & 853 & $(E)$-2-hexenal \\
2 & 1.2 & 928 & Alpha-thujene \\
3 & 0.5 & 936 & Alpha-pinene \\
4 & 0.6 & 977 & 1-Octen-3-ol \\
5 & 2.4 & 989 & Myrcene \\
6 & 1.1 & 1016 & Alpha-terpinene \\
7 & 13.3 & 1025 & p-Cymeno \\
8 & 0.9 & 1032 & $1,8-C y n e o l$ \\
9 & 4.5 & 1059 & Gamma-terpinene \\
10 & 2.8 & 1096 & Linalool \\
11 & 0.4 & 1144 & Ipsdienol \\
12 & 1.1 & 1175 & Umbelulone \\
13 & 0.9 & 1232 & Timil-methyl-ether \\
14 & 9.9 & 1288 & Thymol \\
15 & 49.7 & 1298 & Carvacrol \\
16 & 0.4 & 1369 & Carvacryl acetate \\
17 & 1.5 & 1414 & (E)-beta-caryophyllene \\
18 & 6.4 & 1487 & Unterminated \\
19 & 0.7 & 1566 & Unterminated \\
20 & 1.0 & 1576 & Caryophyllene oxide \\
& Total identified (\%): 92.9 & \\
\hline
\end{tabular}

repellents (Oliveira et al., 2007; Escobar et al., 2010; Vicuña et al., 2010; Betancourt et al., 2012; Caballero-Gallardo et al., 2012; Barreto et al., 2014a, 2014b; Sarrazin et al., 2015a, 2015b; Teles et al., 2014; Vera et al., 2014). However, to the best of our knowledge, there are no existing studies exploring the potential of the essential oil of $L$. origanoides as a treatment against parasites in fish.

Colossoma macropomum Cuvier, 1818 (tambaqui) is an omnivorous fish of the Family Serassalmidae, native to the Amazon. It is an important species in aquaculture, and is cultivated in intensive systems, where high population densities favour parasites transmission (Dias et al., 2015). Such parasites may cause unquantified economic losses, thereby implementation of adequate monitoring and treatments are constant challenges for the farming of this species. Among the most common ectoparasites of farmed C. macropomum are the protozoan Ichthyophthirius multifiliis Fouquet, 1876 and the monogenoideans Anacanthorus spathulatus Kritsky, Thatcher \& Kayton 1979, Notozothecium janauachensis Belmont-Jégu, Domingues \& Martins 2004, Mymarothecium boegeri Cohen \& Kohn, 2005 and Linguadactyloides brinkmanni Thatcher \& Kritsky, 1983 (Dias et al., 2015; Martins et al., 2002; Soares et al., 2016). Products derived from natural plant sources are a potential alternative to the chemical products commonly used in aquaculture to treat parasite infestations

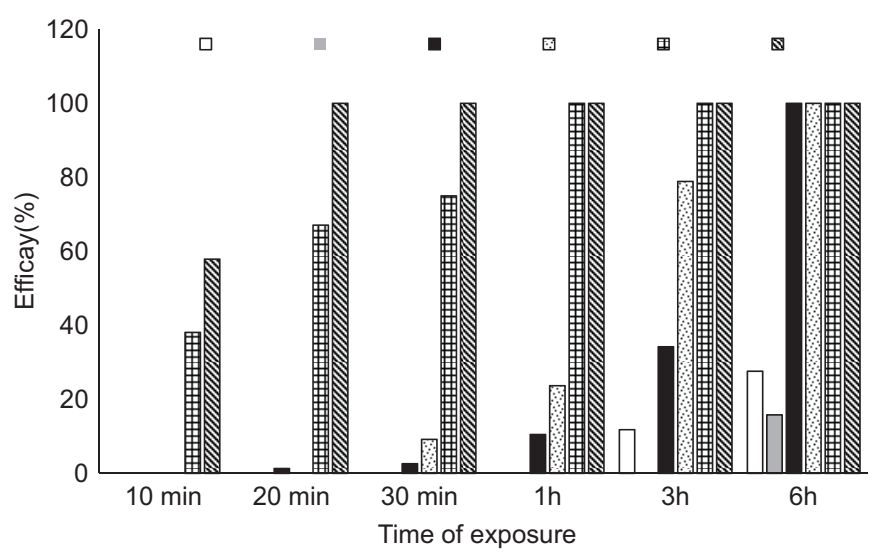

Fig. 1. In vitro efficacy of different concentrations of the essential oil of Lippia origanoides against monogenoideans of Colossoma macropomum $10 \mathrm{mg} \cdot \mathrm{L}^{-1} 20 \mathrm{mg} \cdot \mathrm{L}^{-1} 40 \mathrm{mg} \cdot \mathrm{L}^{-1}$ $80 \mathrm{mg} \cdot \mathrm{L}^{-1} 160 \mathrm{mg} \cdot \mathrm{L}^{-1} 320 \mathrm{mg} \cdot \mathrm{L}^{-1}$
Table 2

In vitro antiparasitic action of the essential oil of Lippia origanoides against monogenoideans of Colossoma macropomum, in relation to the concentration and time of exposure.

\begin{tabular}{|c|c|c|c|}
\hline Time (h) & Treatments & No. of live parasites & Mortality (\%) \\
\hline \multirow[t]{8}{*}{$0 \mathrm{~h}$} & Water & $25.3 \pm 4.5$ & 0 \\
\hline & Water + alcohol & $22.0 \pm 2.6$ & 0 \\
\hline & $10 \mathrm{mg} \cdot \mathrm{L}^{-1}$ & $20.0 \pm 0.0$ & 0 \\
\hline & $20 \mathrm{mg} \cdot \mathrm{L}^{-1}$ & $20.7 \pm 1.2$ & 0 \\
\hline & $40 \mathrm{mg} \cdot \mathrm{L}^{-1}$ & $20.0 \pm 0.0$ & 0 \\
\hline & $80 \mathrm{mg} \cdot \mathrm{L}^{-1}$ & $20.7 \pm 1.2$ & 0 \\
\hline & $160 \mathrm{mg} \cdot \mathrm{L}^{-1}$ & $20.7 \pm 1.2$ & 0 \\
\hline & $320 \mathrm{mg} \cdot \mathrm{L}^{-1}$ & $20.0 \pm 0.0$ & 0 \\
\hline \multirow[t]{8}{*}{$10 \mathrm{~min}$} & Water & $25.3 \pm 4.5$ & 0 \\
\hline & Water + alcohol & $22.0 \pm 2.6$ & 0 \\
\hline & $10 \mathrm{mg} \cdot \mathrm{L}^{-1}$ & $20.0 \pm 0.0$ & 0 \\
\hline & $20 \mathrm{mg} \cdot \mathrm{L}^{-1}$ & $20.7 \pm 1.2$ & 0 \\
\hline & $40 \mathrm{mg} \cdot \mathrm{L}^{-1}$ & $20.0 \pm 0.0$ & 0 \\
\hline & $80 \mathrm{mg} \cdot \mathrm{L}^{-1}$ & $20.7 \pm 1.2$ & 0 \\
\hline & $160 \mathrm{mg} \cdot \mathrm{L}^{-1}$ & $10.7 \pm 4.2$ & 48,3 \\
\hline & $320 \mathrm{mg} \cdot \mathrm{L}^{-1}$ & $5.3 \pm 2.5$ & 73,5 \\
\hline \multirow[t]{8}{*}{$20 \mathrm{~min}$} & Water & $25.3 \pm 4.5$ & 0 \\
\hline & Water + alcohol & $22.0 \pm 2.6$ & 0 \\
\hline & $10 \mathrm{mg} \cdot \mathrm{L}^{-1}$ & $20.0 \pm 0.0$ & 0 \\
\hline & $20 \mathrm{mg} \cdot \mathrm{L}^{-1}$ & $20.7 \pm 1.2$ & 0 \\
\hline & $40 \mathrm{mg} \cdot \mathrm{L}^{-1}$ & $19.7 \pm 0.6$ & 1,5 \\
\hline & $80 \mathrm{mg} \cdot \mathrm{L}^{-1}$ & $18.7 \pm 2.3$ & 9,7 \\
\hline & $160 \mathrm{mg} \cdot \mathrm{L}^{-1}$ & $3.7 \pm 4.7$ & 82,1 \\
\hline & $320 \mathrm{mg} \cdot \mathrm{L}^{-1}$ & $5.3 \pm 2.5$ & 73,5 \\
\hline \multirow[t]{8}{*}{$30 \mathrm{~min}$} & Water & $25.3 \pm 4.5$ & 0 \\
\hline & Water + alcohol & $22.0 \pm 2.6$ & 0 \\
\hline & $10 \mathrm{mg} \cdot \mathrm{L}^{-1}$ & $20.0 \pm 0.0$ & 0 \\
\hline & $20 \mathrm{mg} \cdot \mathrm{L}^{-1}$ & $20.7 \pm 1.2$ & 0 \\
\hline & $40 \mathrm{mg} \cdot \mathrm{L}^{-1}$ & $19.3 \pm 1.2$ & 3,5 \\
\hline & $80 \mathrm{mg} \cdot \mathrm{L}^{-1}$ & $17.7 \pm 3.2$ & 14,5 \\
\hline & $160 \mathrm{mg} \cdot \mathrm{L}^{-1}$ & $1.7 \pm 2.9$ & 91,8 \\
\hline & $320 \mathrm{mg} \cdot \mathrm{L}^{-1}$ & $0.0 \pm 0.0$ & 100 \\
\hline \multirow{8}{*}{$1 \mathrm{~h}$} & Water & $25.3 \pm 4.5$ & 0 \\
\hline & Water + alcohol & $22.0 \pm 2.6$ & 0 \\
\hline & $10 \mathrm{mg} \cdot \mathrm{L}^{-1}$ & $20.0 \pm 0.0$ & 0 \\
\hline & $20 \mathrm{mg} \cdot \mathrm{L}^{-1}$ & $20.7 \pm 1.2$ & 0 \\
\hline & $40 \mathrm{mg} \cdot \mathrm{L}^{-1}$ & $19.0 \pm 1.7$ & 5 \\
\hline & $80 \mathrm{mg} \cdot \mathrm{L}^{-1}$ & $14.7 \pm 2.1$ & 29 \\
\hline & $160 \mathrm{mg} \cdot \mathrm{L}^{-1}$ & $0.0 \pm 0.0$ & 100 \\
\hline & $320 \mathrm{mg} \cdot \mathrm{L}^{-1}$ & $0.0 \pm 0.0$ & 100 \\
\hline \multirow[t]{8}{*}{$3 \mathrm{~h}$} & Water & $25.3 \pm 4.5$ & 0 \\
\hline & Water + alcohol & $20.0 \pm 5.0$ & 9,1 \\
\hline & $10 \mathrm{mg} \cdot \mathrm{L}^{-1}$ & $17.0 \pm 5.2$ & 15 \\
\hline & $20 \mathrm{mg} \cdot \mathrm{L}^{-1}$ & $20.7 \pm 1.2$ & 0 \\
\hline & $40 \mathrm{mg} \cdot \mathrm{L}^{-1}$ & $10.0 \pm 2.0$ & 50 \\
\hline & $80 \mathrm{mg} \cdot \mathrm{L}^{-1}$ & $0.7 \pm 1.2$ & 96,6 \\
\hline & $160 \mathrm{mg} \cdot \mathrm{L}^{-1}$ & $0.0 \pm 0.0$ & 100 \\
\hline & $320 \mathrm{mg} \cdot \mathrm{L}^{-1}$ & $0.0 \pm 0.0$ & 100 \\
\hline \multirow[t]{8}{*}{$6 \mathrm{~h}$} & Water & $4.7 \pm 4.6$ & 81,4 \\
\hline & Water + alcohol & $12.7 \pm 10.7$ & 42,3 \\
\hline & $10 \mathrm{mg} \cdot \mathrm{L}^{-1}$ & $4.3 \pm 2.3$ & 78,5 \\
\hline & $20 \mathrm{mg} \cdot \mathrm{L}^{-1}$ & $2.0 \pm 1.0$ & 90,3 \\
\hline & $40 \mathrm{mg} \cdot \mathrm{L}^{-1}$ & $0.0 \pm 0.0$ & 100 \\
\hline & $80 \mathrm{mg} \cdot \mathrm{L}^{-1}$ & $0.0 \pm 0.0$ & 100 \\
\hline & $160 \mathrm{mg} \cdot \mathrm{L}^{-1}$ & $0.0 \pm 0.0$ & 100 \\
\hline & $320 \mathrm{mg} \cdot \mathrm{L}^{-1}$ & $0.0 \pm 0.0$ & 100 \\
\hline \multirow[t]{8}{*}{$8 \mathrm{~h}$} & Water & $1.3 \pm 2.3$ & 94,9 \\
\hline & Water + alcohol & $1.3 \pm 1.5$ & 94,1 \\
\hline & $10 \mathrm{mg} \cdot \mathrm{L}^{-1}$ & $0.0 \pm 0.0$ & 100 \\
\hline & $20 \mathrm{mg} \cdot \mathrm{L}^{-1}$ & $0.0 \pm 0.0$ & 100 \\
\hline & $40 \mathrm{mg} \cdot \mathrm{L}^{-1}$ & $0.0 \pm 0.0$ & 100 \\
\hline & $80 \mathrm{mg} \cdot \mathrm{L}^{-1}$ & $0.0 \pm 0.0$ & 100 \\
\hline & $160 \mathrm{mg} \cdot \mathrm{L}^{-1}$ & $0.0 \pm 0.0$ & 100 \\
\hline & $320 \mathrm{mg} \cdot \mathrm{L}^{-1}$ & $0.0 \pm 0.0$ & 100 \\
\hline \multirow[t]{8}{*}{$9 \mathrm{~h}$} & Water & $0.0 \pm 0.0$ & 100 \\
\hline & Water + alcohol & $0.0 \pm 0.0$ & 100 \\
\hline & $10 \mathrm{mg} \cdot \mathrm{L}^{-1}$ & $0.0 \pm 0.0$ & 100 \\
\hline & $20 \mathrm{mg} \cdot \mathrm{L}^{-1}$ & $0.0 \pm 0.0$ & 100 \\
\hline & $40 \mathrm{mg} \cdot \mathrm{L}^{-1}$ & $0.0 \pm 0.0$ & 100 \\
\hline & $80 \mathrm{mg} \cdot \mathrm{L}^{-1}$ & $0.0 \pm 0.0$ & 100 \\
\hline & $160 \mathrm{mg} \cdot \mathrm{L}^{-1}$ & $0.0 \pm 0.0$ & 100 \\
\hline & $320 \mathrm{mg} \cdot \mathrm{L}^{-1}$ & $0.0 \pm 0.0$ & 100 \\
\hline
\end{tabular}


(Hashimoto et al., 2016; Huang et al., 2013; Soares et al., 2016). While the potential of two plants of the genus Lippia as sources of anti-parasitic for fish have previously been studied with Lippia sidoides (Hashimoto et al., 2016), and Lippia alba (Soares et al., 2016), the present study represents the first evaluation of this potential use of essential oil of $L$. origanoides.

The aims of this study were to investigate in vivo and in vitro antiparasitic activity of the essential oil of $L$. origanoides against monogenoideans from the gills of $C$. macropomum, and to evaluate the possible impacts on the blood and gills of the fish as a result of essential oil exposure.

\section{Material and methods}

\subsection{Essential oil extraction and composition}

Cultivation of $L$. origanoides and extraction of the essential oil were carried out in the Medicinal Plants and Vegetables sector of Embrapa Western Amazon, in Manaus (03 06'23.04" $\mathrm{S}$ and $60^{\circ} 01^{\prime}$ $35.14^{\prime \prime} \mathrm{W}$ ), state of Amazonas, Brazil. Mean altitude is $50 \mathrm{~m}$ and mean air temperature is $25.6{ }^{\circ} \mathrm{C}$ with annual rainfall of $2200 \mathrm{~mm}$. Plants were collected in the morning and the material processed in the Medicinal Plants and Phytochemistry Laboratory of Embrapa Western Amazon, Manaus (Brazil). The essential oil was obtained from leaves of $L$. origanoides using a Clevenger apparatus. Chemical analysis of the essential oil was carried out by gas chromatography, coupled with a mass spectrometer. The chemical components of the oil used in this study are shown in Table 1.

\subsection{Fish}

The experiments were conducted in the Aquatic Animal Health Lab of Embrapa Amapá (Macapá, state of Amapá, Brazil). Colossoma macropomum fingerling $( \pm 30 \mathrm{~g})$ were obtained from commercial fish farms, and were acclimatised over a 7-day period in $500 \mathrm{~L}$ water tanks, being fed a diet containing $32 \%$ gross protein. The water in the tanks was constantly renewed and the following parameters of the water were monitored: temperature $\left(30.7 \pm 0.2^{\circ} \mathrm{C}\right)$, dissolved oxygen $\left(5.6 \pm 0.4 \mathrm{mg} \cdot \mathrm{L}^{-1}\right), \mathrm{pH}(5.3 \pm 0.2)$, ammonia $\left(0.4 \pm 0.2 \mathrm{mg} \cdot \mathrm{L}^{-1}\right)$, alkalinity $\left(10.0 \pm 0 \mathrm{mg} \cdot \mathrm{L}^{-1}\right)$ and hardness $\left(10.0 \pm 0 \mathrm{mg} \cdot \mathrm{L}^{-1}\right)$ using multiparameters device (YSI, USA). Accumulated organic material was removed from the bottom of the tanks daily.

\subsection{In vitro trial with $L$. origanoides essential oil and monogenoideans of C. macropomum}

To evaluate the concentrations and exposure times necessary to cause mortality, in vitro tests were conducted using monogenoidean parasites collected from the gills of $24 \mathrm{C}$. macropomum fingerling $(11.9 \pm 2.9 \mathrm{~cm}$ e $35.2 \pm 25.0 \mathrm{~g})$, in accordance with the methodology used by Soares et al. (2016). For this trial in Petri dish, two control groups were established, one using only water of the fish culture tank, and the other using tank water and absolute ethanol, which was the solvent used to dilute the essential oil in a ratio of 1:10. Three replicates of six treatment groups were also established with concentrations of 10 ,
20, 40, 80, 160 and $320 \mathrm{mg} \cdot \mathrm{L}^{-1}$ of $L$. origanoides essential oil. Based on the in vitro results, and after a preliminary test of the fish's tolerance to the essential oil, concentrations to be tested in vivo were set as 20 and $40 \mathrm{mg} \cdot \mathrm{L}^{-1}$.

From the in vitro results, the concentrations used in the therapeutic baths with the essential oil of L. alba were determined, after conducting a tolerance test on fish. All in vitro trial were performed at environment temperature of $17^{\circ} \mathrm{C}$ and using stereomicroscopes of cold light.

\subsection{In vivo trial with C. macropomum exposed to L. origanoides essential oil}

Fingerling of $C$. macropomum ( $13.2 \pm 1.1 \mathrm{~cm}$ e $42.4 \pm 10.1 \mathrm{~g}$ ), naturally parasitized by A. spathulatus, $N$. janauachensis and $M$. boegeri, were randomly distributed in twelve $100 \mathrm{~L}$ tanks and maintained in an open water system during $48 \mathrm{~h}$ for acclimation. Three replicates for each treatment and two control groups were established: a control with only water, and a control with water and absolute ethanol at a ratio of 1:10, both exposed for 60 min. Two treatments with $L$. origanoides essential oil at concentrations of $20 \mathrm{mg} \cdot \mathrm{L}^{-1}$ exposed for $60 \mathrm{~min}$ and $40 \mathrm{mg} \cdot \mathrm{L}^{-1}$ exposed for $30 \mathrm{~min}$ were also used. Each replicate consisted of 20 fish, and the water system was maintained at an mean temperature of $30.7 \pm 0.2{ }^{\circ} \mathrm{C}$, dissolved oxygen of $5.6 \pm 0.4 \mathrm{mg} \cdot \mathrm{L}^{-1}$, pH of $5.3 \pm 0.2$, ammonia of $0.4 \pm 0.2 \mathrm{mg} \cdot \mathrm{L}^{-1}$, alkalinity of $10.0 \pm$ $0 \mathrm{mg} \cdot \mathrm{L}^{-1}$ and hardness of $10.0 \pm 0 \mathrm{mg} \cdot \mathrm{L}^{-1}$.

After the required time had passed, the water in the tanks was maintained in continuous flux, and the gills of 10 fish from each replicate were collected and fixed in 5\% formalin, for parasite identification and quantification. The parasites were prepared for identification using previous recommendations (Eiras et al., 2006). Based on quantifications, parasite prevalence and mean abundance of infection were calculated (Bush et al., 1997), and the effectiveness of each treatment was calculated (Zhang et al., 2014). The rest of the specimens were used for histopathological analyses.

Blood was collected from the caudal vein of five fish from each replicate (15 fish per control/treatment group), using syringes with $10 \%$ EDTA, and divided in two aliquots. One aliquot was used for counting red blood cells, determining haematocrit using the micro-haematocrit method and measuring haemoglobin concentration using the cyanmethaemoglobin method. Based on these data, Wintrobe's haematometric indices - mean corpuscular volume (MCV) and mean corpuscular haemoglobin concentration (MCHC) were calculated. Blood smears were prepared and stained with a combination of May Grünwald-Giemsa-Wright (Ranzani-Paiva et al., 2013), and differential leucocyte counts were conducted in up to 200 cells of interest in each blood smear. Identification and nomenclature of leucocytes followed those suggested by Tavares-Dias et al. (1999). The blood smears were also used to count the total number of leucocytes and thrombocytes (Ranzani-Paiva et al., 2013).

A second aliquot of blood was centrifuged at $75 \mathrm{G}$ to obtain plasma for analysis of total glucose and plasma proteins. The concentration of glucose was determined by the enzymatic colorimetric method, and of plasma proteins by the biuret method, using commercial kits (Biotécnica, MG, Brazil). For both biochemical analyses, the readings were made in a spectrophotometer.

Table 3

Prevalence (P) and mean abundance (MA) of the gill parasites in Colossoma macropomum exposed to the essential oil of Lippia origanoides.

\begin{tabular}{|c|c|c|c|c|c|c|c|c|}
\hline \multirow[t]{2}{*}{ Species of parasites } & \multicolumn{2}{|c|}{$\begin{array}{l}\text { Water }(\mathrm{n}=30) \\
60 \text { min }\end{array}$} & \multicolumn{2}{|c|}{$\begin{array}{l}\text { Water }+ \text { alcohol }(n=30) \\
60 \text { min }\end{array}$} & \multicolumn{2}{|c|}{$\begin{array}{l}20 \mathrm{mg} \cdot \mathrm{L}^{-1}(\mathrm{n}=30) \\
60 \mathrm{~min}\end{array}$} & \multicolumn{2}{|c|}{$\begin{array}{l}40 \mathrm{mg} \cdot \mathrm{L}^{-1}(\mathrm{n}=30) \\
30 \mathrm{~min}\end{array}$} \\
\hline & $\mathrm{P}(\%)$ & MA & $\mathrm{P}(\%)$ & MA & $\mathrm{P}(\%)$ & MA & $\mathrm{P}(\%)$ & MA \\
\hline Ichthyophthirius multifiliis & 96.3 & $80.3 \pm 47.0^{\mathrm{ab}}$ & 96.7 & $67.2 \pm 38.5^{\mathrm{a}}$ & 90 & $108.5 \pm 79.9^{b}$ & 82.6 & $52.7 \pm 59.1^{\mathrm{a}}$ \\
\hline Monogenoidea species & 100 & $341.3 \pm 67.3^{\mathrm{a}}$ & 100 & $333.7 \pm 86.9^{\mathrm{a}}$ & 100 & $316.2 \pm 79.3^{\mathrm{a}}$ & 100 & $352.3 \pm 67.3^{\mathrm{a}}$ \\
\hline
\end{tabular}

Different letters on the same line indicate significant differences by Dunn test $(\mathrm{p}<0.05$ ). 
Table 4

Blood parameters of Colossoma macropomum exposed to the essential oil of Lippia origanoides.

\begin{tabular}{|c|c|c|c|c|}
\hline Parameters & Water $(\mathrm{n}=15)$ & $\begin{array}{l}\text { Water + alcohol } \\
(\mathrm{n}=15)\end{array}$ & $\begin{array}{l}20 \mathrm{mg} \cdot \mathrm{L}^{-1} \\
(\mathrm{n}=15)\end{array}$ & $\begin{array}{l}40 \mathrm{mg} \cdot \mathrm{L}^{-1} \\
(\mathrm{n}=15)\end{array}$ \\
\hline Body weight (g) & $42.4 \pm 11.5^{\mathrm{a}}$ & $40.6 \pm 8.5^{\mathrm{a}}$ & $41.2 \pm 8.9^{\mathrm{a}}$ & $39.3 \pm 9.0^{\mathrm{a}}$ \\
\hline Length $(\mathrm{cm})$ & $13.6 \pm 1.2^{\mathrm{a}}$ & $13.1 \pm 0.9^{a}$ & $12.9 \pm 1.0^{\mathrm{a}}$ & $13.0 \pm 1.3^{\mathrm{a}}$ \\
\hline Glucose $\left(\mathrm{g} \cdot \mathrm{dL}^{-1}\right)$ & $97.5 \pm 16.9^{a}$ & $104.2 \pm 25.4^{\mathrm{a}}$ & $99.8 \pm 21.6^{\mathrm{a}}$ & $99.4 \pm 21.6^{\mathrm{a}}$ \\
\hline Proteins $\left(\mathrm{mg} \cdot \mathrm{dL}^{-1}\right)$ & $2.5 \pm 0.4^{\mathrm{a}}$ & $3.2 \pm 0.8^{\mathrm{a}}$ & $3.6 \pm 1.1^{\mathrm{b}}$ & $3.6 \pm 0.5^{\mathrm{b}}$ \\
\hline Erythrocytes $\left(\times 10^{6} \cdot \mu \mathrm{L}^{-1}\right)$ & $1.07 \pm 0.15^{\mathrm{a}}$ & $1.13 \pm 0.23 a$ & $1.18 \pm 0.47 a$ & $0.96 \pm 0.17 a$ \\
\hline Haemoglobin $\left(\mathrm{g} \cdot \mathrm{dL}^{-1}\right)$ & $5.3 \pm 0.6 a$ & $5.6 \pm 0.5^{\mathrm{b}}$ & $5.0 \pm 0.6 a$ & $5.0 \pm 0.5 a$ \\
\hline Haematocrit (\%) & $17.5 \pm 1.5^{\mathrm{a}}$ & $17.7 \pm 2.4^{\mathrm{a}}$ & $15.8 \pm 1.7^{\mathrm{b}}$ & $15.1 \pm 1.8^{b}$ \\
\hline $\operatorname{MCV}(\mathrm{fL})$ & $166.0 \pm 25.5^{\mathrm{a}}$ & $160.9 \pm 28.9^{\mathrm{a}}$ & $145.9 \pm 38.6 a$ & $162.2 \pm 37.8^{\mathrm{a}}$ \\
\hline $\mathrm{MCHC}\left(\mathrm{g} \cdot \mathrm{dL}^{-1}\right)$ & $30.4 \pm 2.6^{\mathrm{a}}$ & $32.3 \pm 4.6 a$ & $31.7 \pm 2.5^{\mathrm{a}}$ & $33.2 \pm 4.1^{\mathrm{a}}$ \\
\hline Thrombocytes $(\mu \mathrm{L})$ & $26,144 \pm 9993^{a}$ & $22,980 \pm 7965^{a}$ & $23,434 \pm 10,704^{a}$ & $20,325 \pm 5129^{a}$ \\
\hline Leukocytes $(\mu \mathrm{L})$ & $10,114 \pm 2524^{\mathrm{a}}$ & $9702 \pm 4541^{\mathrm{a}}$ & $12,895 \pm 5465^{a}$ & $11,761 \pm 3412^{\mathrm{a}}$ \\
\hline Lymphocytes $(\mu \mathrm{L})$ & $6566 \pm 2235^{\mathrm{a}}$ & $5695 \pm 2398^{a}$ & $4800 \pm 2287^{a}$ & $5499 \pm 2040^{\mathrm{a}}$ \\
\hline Monocytes $(\mu \mathrm{L})$ & $1075 \pm 338^{a}$ & $1150 \pm 549^{a}$ & $2659 \pm 1164^{b}$ & $1661 \pm 960^{\mathrm{b}}$ \\
\hline Neutrophils $(\mu \mathrm{L})$ & $2272 \pm 1057^{\mathrm{a}}$ & $2444 \pm 1521^{\mathrm{a}}$ & $5197 \pm 2031^{b}$ & $4489 \pm 2012^{b}$ \\
\hline Eosinophils $(\mu \mathrm{L})$ & $27 \pm 38^{\mathrm{a}}$ & $9 \pm 28^{\mathrm{a}}$ & $14 \pm 32^{\mathrm{a}}$ & $22 \pm 43^{a}$ \\
\hline PAS-GL $(\mu \mathrm{L})$ & $173 \pm 306^{\mathrm{a}}$ & $392 \pm 774^{\mathrm{a}}$ & $324 \pm 396^{\mathrm{a}}$ & $89 \pm 77^{a}$ \\
\hline
\end{tabular}

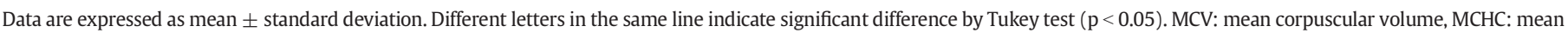
corpuscular haemoglobin concentration, PAS-positive granular leukocytes (PAS-GL).

\subsection{Histopathological analyses of C. macropomum gills exposed to L. origanoides essential oil}

The gills of six fish per treatment/control group (two fish per replicate) were used for histopathological analyses immediately after the end of the experiment. Twenty four hours post treatment, the gills of another six fish per treatment/control group (two fish per replicate) were also analysed, to look for recuperation. The first right gill arch of each fish was collected and fixed in formalin (10\%), then dehydrated through a gradual series of ethanol and xylol, embedded in paraffin and cut with a microtome to produce consecutive sections. The histological sections were stained with haematoxylin and eosin (HE) and viewed under a light microscope (Soares et al., 2016). The histopathological analysis was performed semi-quantitatively using the mean assessment values (MAV) (Schwaiger et al., 1997) and the histopathological alteration index (HAI) (Poleksic and Mitrovic-Tutundzic, 1994).

\subsection{Statistical analyses}

Shapiro-Wilk and Bartlett tests were used to check for normality and homoscedasticity, respectively, and as the data did not meet these assumptions, a Kruskal-Wallis followed by Tukey test were used to compare the medians $(\mathrm{p}<0.05)$.

\section{Results}

3.1. In vitro anti-parasitic action of $L$. origanoides essential oil against monogenoideans

Concentrations of essential oil of 320 and $160 \mathrm{mg} \cdot \mathrm{L}^{-1}$ were $100 \%$ effective against $A$. spathulatus, $N$. janauachensis and $M$. boegeri from the gills of $C$. macropomum with 30 and 60 min exposure, respectively. At a concentration of $80 \mathrm{mg} \cdot \mathrm{L}^{-1}$, the essential oil was approximately $80 \%$ effective with $3 \mathrm{~h}$ of exposure, reaching $100 \%$ with $6 \mathrm{~h}$ of exposure. The oil was also $100 \%$ effective at a concentration of $40 \mathrm{mg} \cdot \mathrm{L}^{-1}$, with $6 \mathrm{~h}$ of exposure. The two lower concentrations, of 10 and $20 \mathrm{mg} \cdot \mathrm{L}^{-1}$, were not very effective, failing to reach $40 \%$ mortality in $6 \mathrm{~h}$ of exposure, and requiring $8 \mathrm{~h}$ to reach $100 \%$ mortality. In the control groups, mortality began after $3 \mathrm{~h}$ (only water) and $1 \mathrm{~h}$ (water + alcohol), and in both groups $100 \%$ mortality occurred after 8 h (Fig. 1 and Table 2).

\subsection{Antiparasitic action of L. origanoides essential oil in C. macropomum}

There was no difference in abundance of $A$. spatulathus, M. boegeri, $N$. janauachensis or I. multifiliis between control and treatment groups (Table 3), indicating that, at the concentrations used, the essential oil was not effective against these gill parasites. During the application of

Table 5

Mean alteration value (MAV) and histopathological alteration index (HAI) of the gills of Colossoma macropomum exposed to the essential oil of Lippia origanoides.

\begin{tabular}{|c|c|c|c|c|}
\hline Treatments & $\mathrm{n}$ & MAV & HAI & Severity of the lesions according to the HAI \\
\hline \multicolumn{5}{|c|}{ After 30 min therapeutic bath } \\
\hline Water & 6 & $1.3 \pm 0.5^{\mathrm{aA}}$ & $46.3 \pm 49.8^{\mathrm{aA}}$ & Moderate to severe alterations to the gills \\
\hline Water + alcohol & 6 & $1.2 \pm 0.4^{\mathrm{aA}}$ & $16.5 \pm 7.9^{\mathrm{aA}}$ & Low to moderate alterations to the gills \\
\hline $\begin{array}{l}20 \mathrm{mg} \cdot \mathrm{L}^{-1} \\
60 \mathrm{~min}\end{array}$ & 6 & $1.8 \pm 0.4^{\mathrm{aA}}$ & $87.3 \pm 59.6^{\mathrm{aA}}$ & Severe alterations to the gills \\
\hline $\begin{array}{l}40 \mathrm{mg} \cdot \mathrm{L}^{-1} \\
30 \mathrm{~min}\end{array}$ & 6 & $1.7 \pm 0.8^{\mathrm{aA}}$ & $51.2 \pm 54.6^{\mathrm{aA}}$ & Severe alterations to the gills \\
\hline \multicolumn{5}{|c|}{ After $24 \mathrm{~h}$ of recovery subsequent to therapeutic bath } \\
\hline Water & 6 & $1.2 \pm 0.4^{\mathrm{aA}}$ & $16.0 \pm 7.8^{\mathrm{aA}}$ & Low to moderate alterations to the gills \\
\hline Water + alcohol & 6 & $1.2 \pm 0.4^{\mathrm{aA}}$ & $18.2 \pm 5.7^{\mathrm{aA}}$ & Low to moderate alterations to the gills \\
\hline $\begin{array}{l}20 \mathrm{mg} \cdot \mathrm{L}^{-1} \\
60 \mathrm{~min}\end{array}$ & 6 & $1.5 \pm 0.5^{\mathrm{aA}}$ & $52.0 \pm 53.7^{\mathrm{aA}}$ & Severe alterations to the gills \\
\hline $\begin{array}{l}40 \mathrm{mg} \cdot \mathrm{L}^{-1} \\
30 \mathrm{~min}\end{array}$ & 6 & $1.3 \pm 0.5^{\mathrm{aA}}$ & $13.7 \pm 9.7^{\mathrm{aA}}$ & Low to moderate alterations to the gills \\
\hline
\end{tabular}

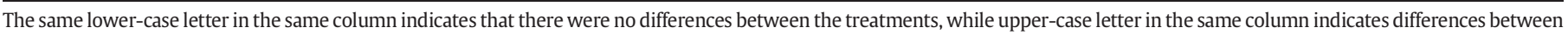
the times, according to the Tukey test $(\mathrm{p}<0.05)$. 
the therapeutic baths, the following behaviours were observed in the fish: normal in the water-only control, moderate agitation in the water + alcohol control, and immobilization and sinking to the bottom of the tank in both essential oil treatments. After the end of the bath, when a continuous water flow was re-established, the fish in the treatment groups gradually returned to normal swimming behaviour, and there was no fish mortality recorded.

3.3. Effects on blood parameters in C. macropomum exposed to L. origanoides essential oil

The level of plasma proteins, and the number of monocytes and neutrophils increased in fish exposed to the essential oil at both concentrations (20 and $40 \mathrm{mg} \cdot \mathrm{L}^{-1}$ ), and haematocrit declined, while other measured parameters showed no change. The $60 \mathrm{~min}$ bath in water + alcohol led to an increase in haemoglobin, relative to fish in the other control and treatment groups (Table 4).

\subsection{Histopathological effects on the gills of $C$. macropomum exposed to L. origanoides essential oil}

Immediately and $24 \mathrm{~h}$ after therapeutic baths, there was no change in MAV or HAI among treatments. Unfortunately, after exposure to the $L$. origanoides essential oil, the severity of gill lesions in treated fish varied from those in the water-treated control group, in accordance with the index of histopathological change, with

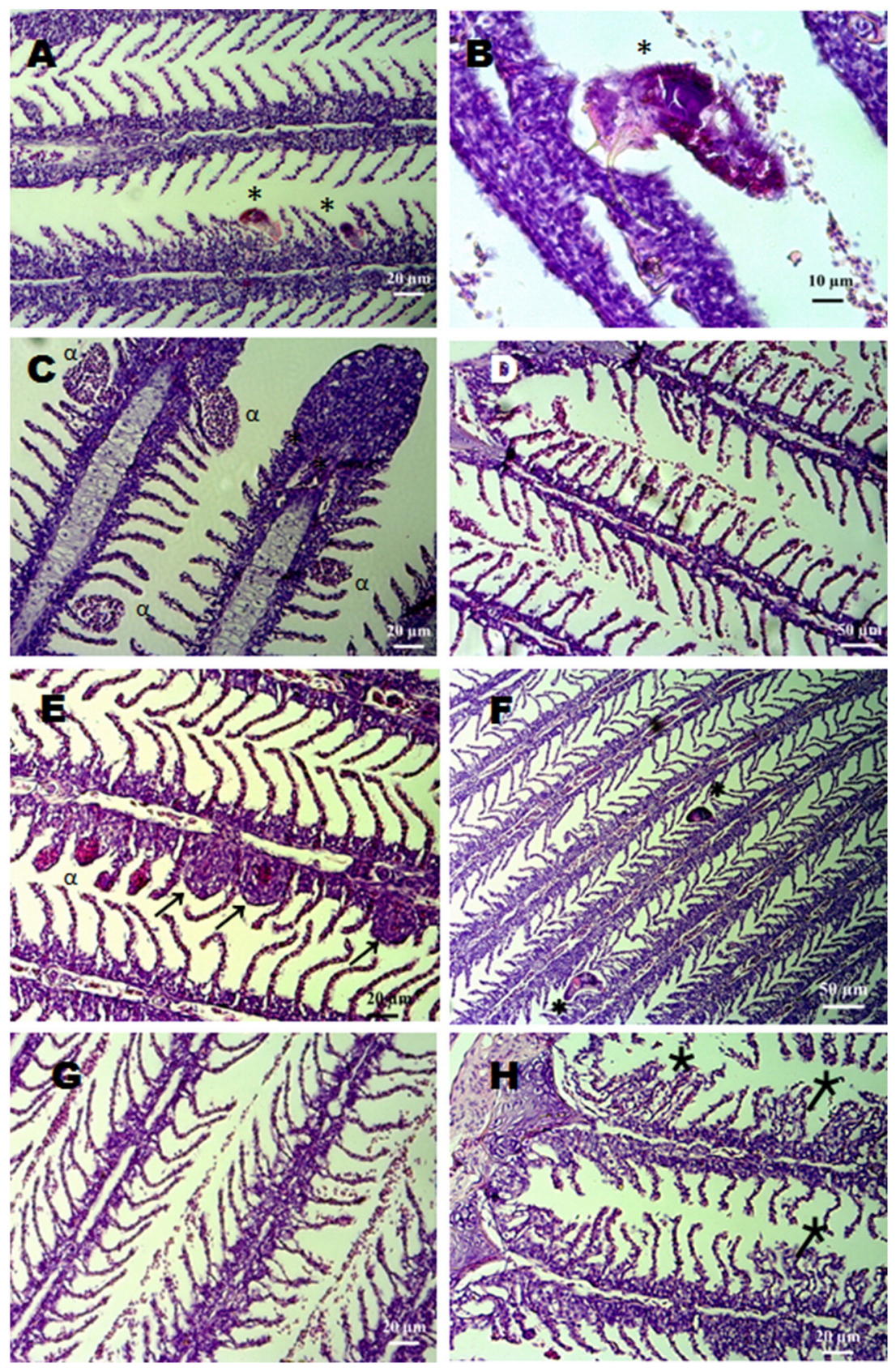

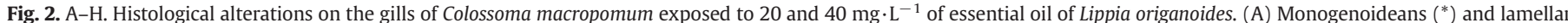

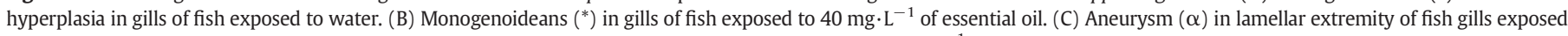

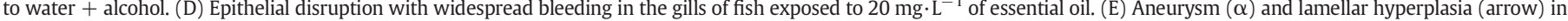

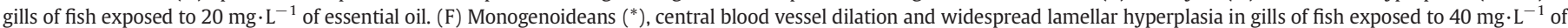

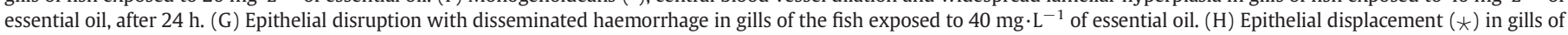
the fish exposed to $40 \mathrm{mg} \cdot \mathrm{L}^{-1}$ of essential oil after $24 \mathrm{~h}$ of recovery. 
moderate to severe damage recorded. Slight to moderate damage was recorded on gills of fish in the water + alcohol control group. After the $24 \mathrm{~h}$ recuperation period, the gills of fish in the two control groups and the $40 \mathrm{mg} \cdot \mathrm{L}^{-1}$ treatment group were slightly to moderately damaged, while the gills of fish in the $20 \mathrm{mg} \cdot \mathrm{L}^{-1}$ treatment groups were severely damaged (Table 5). Histological changes (hyperplasia and fusion of the lamellar epithelium, capillary dilation, displacement of the lamellar epithelium, and lamellar aneurism and epithelial rupturing with haemorrhaging) are shown in Fig. 2A-H. Oedema, mucous and chloride cell proliferation, lamellar hypertrophy, congestion and necrosis were less frequently observed.

\section{Discussion}

Analysis of the $L$. origanoides essential oil used in this study indicated that its major chemical constituents are carvacrol, p-cymene and thymol. Similar results have been reported previously with $L$. origanoides essential oil (Teles et al., 2014; Ribeiro et al., 2014; Sarrazin et al., 2015a, 2015b; Vera et al., 2014; and Vicuña et al., 2010). Thymol and carvacrol have been shown to have antimicrobial, antigenotoxic and anti-protozoal properties, and may therefore be responsible for the bioactive effects of $L$. origanoides essential oil (Nostro et al., 2004; Sarrazin et al., 2015a, 2015b; Vicuña et al., 2010; Escobar et al., 2010). However, bioactivity may also be due to a synergism of the chemical components of the essential oil (Barreto et al., 2014a).

The in vitro test showed that at low concentrations $(10,20$, $40 \mathrm{mg} \cdot \mathrm{L}^{-1}$ ) the $L$. origanoides essential oil was not an efficient antiparasitic against the monogenoideans A. spatulathus, $M$. boegeri and $N$. janauachensis, while higher concentrations (80, 160 and $320 \mathrm{mg} \cdot \mathrm{L}^{-1}$ ) had a dose-dependent efficacy. Soares et al. (2016) also showed a dose-dependent efficacy of the essential oil of $L$. alba against these same parasites, using concentrations of $160,320,640$, 1280 and $2560 \mathrm{mg} \cdot \mathrm{L}^{-1}$. Essential oil trials with $\mathrm{L}$. sidoides, at concentrations of $40,80,160$ and $320 \mathrm{mg} \cdot \mathrm{L}^{-1}$ have also shown that the highest concentrations ( 160 and $320 \mathrm{mg} \cdot \mathrm{L}^{-1}$ ) were effective against the monogenoideans Cichlidogyrus tilapiae, Cichlidogyrus thurstonae, Cichlidogyrus halli and Scutogyrus longicorni, from the gills of Oreochromis niloticus (Hashimoto et al., 2016). Despite being congeneric species, different concentrations and chemical compositions may have influenced the effectiveness of these three essential oils against the parasites in vitro.

An anaesthetic effect was observed in the C. macropomum during the therapeutic baths with concentrations of both 20 and $40 \mathrm{mg} \cdot \mathrm{L}^{-1}$ of the $L$. origanoides essential oil. A similar effect was reported for $C$. macropomum exposed to 100 and $150 \mathrm{mg} \cdot \mathrm{L}^{-1}$ of $\mathrm{L}$. alba essential oil (Soares et al., 2016) and 0 . niloticus exposed to $40 \mathrm{mg} \cdot \mathrm{L}^{-1}$ of $L$. sidoides essential oil (Hashimoto et al., 2016). Furthermore, the baths showed no efficacy against the monogenoideans $A$. spatulathus, $M$. boegeri and $N$. janauachensis, or against I. multifiliis. However, therapeutic baths with extracts of Caesalpinia sappan, Lysima chiachristinae, Cuscuta chinensis, Artemisia argyi, and Eupatorium fortunei have shown efficacy against Dactylogyrus intermedius parasitizing Carassius auratus (Huang et al., 2013). Ji et al. (2012) also found anthelmintic activity against $D$. intermedius parasitizing C. auratus using extracts of Cinnamomum cassia, Lindera aggregata and Pseudolarix kaempferi. The present study represents the first trial of $L$. origanoides as an antiparasitic in fish.

Plasma protein concentrations and the number of monocytes and neutrophils, increased in C. macropomum exposed to 20 and $40 \mathrm{mg} \cdot \mathrm{L}^{-1}$ of the $L$. origanoides essential oil, whereas haematocrit decreased. These results are similar to those of Soares et al. (2016) who found decreased haematocrit and increased plasma protein concentrations and neutrophil numbers in C. macropomum exposed to 100 and $150 \mathrm{mg} \cdot \mathrm{L}^{-1}$ of $L$. alba essential oil, and those of Hashimoto et al. (2016) who found increased numbers of neutrophils in 0 . niloticus exposed to $40 \mathrm{mg} \cdot \mathrm{L}^{-1}$ of $L$. sidoides essential oil. Therefore, in summary, evidence shows that the essential oils of Lippia congeneric species, when used in low concentrations in therapeutic bathing, cause moderate changes in the blood of exposed fish.

Our results show damage to the gills after exposure to $L$. origanoides essential oil. However, these lesions were most likely caused by the parasites themselves as they occurred frequently in all treatments and controls. Indeed, $L$. origanoides essential oil has been previously shown to not be very cytotoxic in rat (Sarrazin et al., 2015b), insect (CaballeroGallardo et al., 2012) and other mammalian cells (Escobar et al., 2010). Furthermore, similar gill lesions have also been described for Piaractus brachypomus (Verján et al., 2001) and Rachycentron canadum (Guerra-Santos et al., 2012), infected by different species of parasites. However, severe and irreparable damage to gills has been previously reported for $C$. macropomum exposed to the essential oil of $L$. alba at concentrations of 100 and $150 \mathrm{mg} \cdot \mathrm{L}^{-1}$ (Soares et al., 2016). The diluted alcohol used as a control in this study did not cause blood and histopathology alteration in the gills of $C$. macropomum, as have been recorded for some other types of diluents (Hashimoto et al., 2016; Steverding et al., 2005).

\section{Conclusions}

The essential oil of Lippia origanoides possesses antiparasitic properties in vitro, with dose-dependent efficacy. However, even at the low concentrations tested here, the oil has an anaesthetic effect on C. macropomum, and furthermore, although it causes few histopathological and blood changes, at these concentrations it is not effective against parasites of $C$. macropomum. As such, $L$. origanoides essential oil can not be recommended as a treatment against ectoparasites. However, owing to its in vitro effects, in vivo trials should now be conducted using the constituent components of $L$. origanoides essential oil to test their efficacy against parasites of this fish species, and their effects on host fish.

\section{Acknowledgments}

The authors thank the National Council for Scientific and Technological Development (Conselho Nacional de Desenvolvimento Científico e Tecnológico, CNPq) for financial support (\#472054/2013-9) and FAPEAM (\#PPP-392/2012). Dr. M. Tavares-Dias was also supported by a Research fellowship from CNPq/Brazil (\#303013/2015-0).

\section{References}

Barreto, H.M., Fontinele, F.C., Oliveira, A.P., Arcanjo, D.D.R., Santos, B.H.C., Abreu, A.P.L., Coutinho, H.D.M., Silva, R.A.C., Sousa, T.O., Medeiros, M.G.F., Citó, A.M.G.L., Lopes, J.A.D., 2014a. Phytochemical prospection and modulation of antibiotic activity in vitro by Lippia origanoides H.B.K. in methicillin resistant Staphylococcus aureus. Hindawi Publishing Corporation Biomed. Res. Int., ID 305610, http://dx.doi.org/10. $1155 / 2014 / 305610$.

Barreto, H.M., Lima, I.S., Coelho, K.M.R.N, Osório, L.R., Mourão, R.A., Santos, B.H.C., Coutinho, H.D.M., Abreu, A.P.L., Medeiros, M.G.F., Citó, A.M.G.L., Lopes, J.A.D., 2014b. Effect of Lippia origanoides H.B.K. essential oil in the resistance to aminoglycosides in methicillin resistant Staphylococcus aureus. Europ. J. Integ. Med. 6, 560-564.

Betancourt, L., Phandanauvong, V., Patiño, R., Ariza-Nieto, C., Afanador-Téllez, G., 2012. Composition and bactericidal activity against beneficial and pathogenic bacteria of oregano essential oils from four chemotypes of Origanum and Lippia genus. Rev. Med. Vet. Zoot. 59 (1), 21-31.

Bush, A.O., Lafferty, K.D., Lotz, J.M., Shostack, A.W., 1997. Parasitology meets ecology on its own terms: Margolis et al. revisited. J. Parasitol. 83 (4), 575-583.

Caballero-Gallardo, K., Olivero-Verbel, J., Stashenko, E.E., 2012. Repellency and toxicity of essential oils from Cymbopogon martinii, Cymbopogon flexuosus and Lippia origanoides cultivated in Colombia against Tribolium castaneum. J. Stored Prod. Res. 50, 62-65.

Dias, M.K.R., Neves, L.R., Marinho, R.G.B., Tavares-Dias, M., 2015. Parasitic infections in tambaqui from eight fish farms in Northern Brazil. Arq. Bras. Med. Vet. Zoot. 67 (4), 1070-1076.

Eiras, J.C., Takemoto, R.M., Pavanelli, G.C., 2006. Métodos de estudos e técnicas laboratoriais em parasitologia de peixes. Maringá, Editora UEM, p. 173.

Escobar, P., Leal, S.M., Herrera, L.V., Martinez, J.R., Stashenko, 2010. Chemical composition and antiprotozoal activities of Colombian Lippia spp. essential oils and their major components. Mem. Inst. Oswaldo Cruz 105 (2), 184-190. 
Guerra-Santos, B., Albinati, R.C.B., Moreira, E.L.T., Lima, F.W.M., Azevedo, T.M.P., Costa, D.S.P., Medeiros, S.D.C., Lira, A.D., 2012. Parâmetros hematológicos e alterações histopatológicas em bijupirá (Rachycentron canadum Linnaeus, 1766) com amyloodiniose. Pesqui. Vet. Bras. 32 (11), 1184-1190.

Hashimoto, G.S.O., Neto, F.M., Ruiz, M.L., Achille, M., Chagas, E.C., Chaves, F.C.M., Martins, M.L., 2016. Essential oils of Lippia sidoides and Mentha piperita against monogenean parasites and their influence on the hematology of Nile tilápia. Aquaculture 450, 182-186.

Huang, A.G., Yi, Y.L., Ling, F., Lu, L., Zhang, Q.Z., Wang, G.X., 2013. Screening of plant extracts for anthelmintic activity against Dactylogyrus intermedius (Monogenea) in goldfish (Carassius auratus). Parasitol. Res. 112, 4065-4072.

Ji, J., Lu, C., Kang, Y., Wang, G.X., Chen, P., 2012. Screening of 42 medicinal plants for in vivo anthelmintic activity against Dactylogyrus intermedius (Monogenea) in goldfish (Carassius auratus). Parasitol. Res. 111, 97-104.

Martins, M.L., Moraes, F.R., Fujimoto, R.Y., Nomura, D.T., Fenerick Jr., J., 2002. Respostas do híbrido tambacu (Piaractus mesopotamicus Holmberg, 1887 macho X Colossoma macropomum Cuvier, 1818 fêmea) a estímulos simples ou consecutivos de captura. Bol. Inst. Pesca. 28 (2), 195-204.

Nostro, A., Blanco, A.R., Cannatelli, M.A., Enea, V., Flamini, G., Morelli, I., Roccaro, A.S., Alonzo, V., 2004. Susceptibility of methicillin-resistant staphylococci to oregano essential oil, carvacrol and thymol. FEMS Microbiol. Lett. 230, 191-195.

Oliveira, D.R., Leitão, G.G., Bizzo, H.R., Lopes, D., Alviano, D.S., Alviano, C.S., Leitão, S.G., 2007. Chemical and antimicrobial analyses of essential oil of Lippia origanoides H.B.K. Food Chem. 101, 236-240.

Poleksic, V., Mitrovic-Tutundzic, V., 1994. Fish gills as a monitor of sublethal and chronic effects of pollution. In: Muller, R., Lloyd, R. (Eds.), Sublethal and Chronic Effects of Pollutants on Freshwater Fish. Fishing News Books, Oxford, pp. 339-352.

Ranzani-Paiva, M.J.T., Padua, S.B., Tavares-Dias, M., Egami, M.I., 2013. Métodos para análises hematológicas em peixes. EDUEM, Maringá, p. 135.

Ribeiro, A.F., Andrade, E.H., Salimena, F.R.G., Maia, J.G.S., 2014. Circadian and seasonal study of the cinnamate chemotype from Lippia origanoides Kunth. Biochem. Syst. Ecol. 55, 249-259.

Sarrazin, S.L.F., Silva, L.A., Assunção, A.P.F., Oliveira, R.B., Calao, V.Y.P., Silva, R., Stashenko, E.E., Maia, J.G.S., Mourão, R.H., 2015a. Antimicrobial and seasonal evaluation of the carvacrol-chemotype oil from Lippia origanoides Kunth. Molecules 20, 1860-1871.

Sarrazin, S.L., Silva, L.A., Oliveira, R.B., Raposo, J.D.A., Silva, J.K.R., Salimena, F.R.G., Maia, J.G.S., Mourão, R.H.V., 2015b. Antibacterial action against food-borne microorganisms and antioxidant activity of carvacrol-rich oil from Lippia origanoides Kunth. Health Dis. $14,145$.
Schwaiger, J., Wanke, R., Adam, S., Pawert, M., Honnen, W., Triebskorn, R., 1997. The use of histopathological indicators to evaluate contaminant-related stress in fish. J. Aquat. Ecosyst. Stress. Recover. 6, 75-86.

Soares, B.V., Tavares-Dias, M., 2013. Espécies de Lippia (Verbenaceae), seu potencial bioativo e importância na medicina veterinária e aquicultura. Biota Amazônia 3 (1) $109-123$.

Soares, B.V., Neves, L.R., Oliveira, M.S.B., Chaves, F.C.M., Dias, M.K.R., Chagas, E.C., TavaresDias, M., 2016. Antiparasitic activity of the essential oil of Lippia alba on ectoparasites of Colossoma macropomum (tambaqui) and its physiological and histopathological effects. Aquaculture 452, 107-114.

Steverding, D., Morgan, E., Tkacynski, P., Walder, F., Tinsley, R., 2005. Effect of Australian tea tree oil on Gyrodactylus spp., infection of the three-spined stickleback Gasterosteus aculeatus. Dis. Aquat. Org. 66, 29-32.

Tavares-Dias, M., Sandrin, E.F.S., Campos-Filho, E., 1999. Características hematológicas do tambaqui Colossoma macropomum Cuvier (Osteichthyes: Characidae) em sistema de monocultivo intensivo. II. Leucócitos. Rev. Brasil. Zool. 16, 175-184.

Teles, S., Pereira, J.A., Oliveira, L.M., Malheiro, R., Machado, S.S., Lucchese, A.M., Silva, F., 2014. Organic and mineral fertilization influence on biomass and essential oil production, composition and antioxidant activity of Lippia origanoides H.B.K. Ind. Crop. Prod. 59, 169-176.

Vásquez, S.P.F., Mendonça, M.S., Noda, S.N., 2014. Etnobotânica de plantas medicinais em comunidades ribeirinhas do município de Manacapuru, Amazonas, Brasil. Acta Amaz 44 (4), 457-472.

Vera, S.S., Zambrano, D.F., Méndez-Sánchez, S.C., Rodríguez-Sanabria, F., Stashenko, E.E. Luna, J.E.D., 2014. Essential oils with insecticidal activity against larvae of Aedes aegypti (Diptera: Culicidae). Parasitol. Res. 113, 2647-2654.

Verján, N., Iregui, C.A., Rey, A.L., Donado, P., 2001. Sistematización y caracterización de lãs lesiones branquiales de la cachama blanca (Piaractus brachypomus) de cultivo clínicamente sana: algunas interacciones hospedador-patógeno-ambiente. Rev. Aquatic 15, 1-15.

Vicuña, G.C., Stashenko, E.E., Fuentes, J.L., 2010. Chemical composition of the Lippia origanoides essential oils and their antigenotoxicity against bleomycin-induced DNA damage. Fitoterapia 81, 343-349.

Zhang, X.P., Li, W.X., Ai, T.S., Zou, H., Wu, S.G., Wang, G.T., 2014. The efficacy of four common anthelmintic drugs and traditional Chinese medicinal plant extracts to control Dactylogyrus vastator (Monogenea). Aquaculture (420-421), 302-307. 